\title{
A tale of the two PEGylated liposomal doxorubicins
}

\author{
Hunghsueh Chou ${ }^{1,4}$ \\ Hao Lin ${ }^{2,4}$ \\ Jacqueline M Liu ${ }^{3}$ \\ 'Department of Obstetrics and \\ Gynecology, Linkou Chang Gung \\ Memorial Hospital, Linkou, Taiwan; \\ ${ }^{2}$ Department of Obstetrics and \\ Gynecology, Kaohsiung Chang Gung \\ Memorial Hospital, Linkou, Taiwan; \\ ${ }^{3}$ TTY Oncology Translational Research \\ Center, TTY Biopharm, Taipei, Taiwan; \\ ${ }^{4}$ Chang Gung University College of \\ Medicine, Linkou, Taiwan
}

This article was published in the following Dove Press journal:

OncoTargets and Therapy

13 July 2015

Number of times this article has been viewed

\section{Dear editor}

We are writing this letter in response to the article "Outcomes analysis of an alternative formulation of PEGylated liposomal doxorubicin in recurrent epithelial ovarian carcinoma during the drug shortage era" by Berger et al and published in August $2014 .{ }^{1}$ This paper is one of the earliest reports of the outcome of using Lipodox ${ }^{\circledR}$ available in the Western medical literature.

There are two PEGylated liposomal doxorubicin formulations, with the brand names Lipodox and Lipo-Dox ${ }^{\circledR}$. Lipodox is manufactured by Sun Pharma and has been approved by the US Food and Drug Administration as a generic of Doxil ${ }^{\circledR}$ since February 4, 2013. ${ }^{2}$ Lipo-Dox is manufactured by TTY Biopharm, and has a lipid formulation different to that of Doxil and has a longer half-life; ${ }^{3}$ it has been sold in Taiwan and many Asian countries since 1998, and is probably the alternative formulation referenced in the paper by Berger et al. ${ }^{1}$

Berger et al incorrectly referenced two Asian ovarian cancer trials for efficacy and survival data for Lipodox, and we need to set the record straight that the Taiwanese trial used TTY Biopharm Lipo-Dox, ${ }^{4}$ and that the Japanese trial most likely used the originator Doxil. ${ }^{5}$ Another smaller study using single-agent TTY Biopharm Lipo-Dox in patients with ovarian cancer refractory to both cisplatin and paclitaxel produced efficacy similar to that reported by Chou et $\mathrm{al}^{6}$ but with no serious toxicity because of a slightly lower dose (see Table 1).

\section{Disclosure}

The authors report no conflicts of interest in this communication.

Table I Clinical trials reporting single-agent liposomal doxorubicin therapy for refractory ovarian cancer, with dosage, response, survival, and toxicity information

\begin{tabular}{|c|c|c|c|c|c|c|c|}
\hline & & $\begin{array}{l}\text { Ovarian } \\
\text { cancer }\end{array}$ & $\begin{array}{l}\text { Patients } \\
\text { (n) }\end{array}$ & $\begin{array}{l}\text { Dosel } \\
4 \text { weeks }\end{array}$ & ORR & $\begin{array}{l}\text { PFS/OS } \\
\text { months }\end{array}$ & $\begin{array}{l}\text { Grade } \\
3+4 \text { toxicity }\end{array}$ \\
\hline Berger et al' & Lipodox $^{\circledR}$ & Recurrent & 18 & $30 \mathrm{mg} / \mathrm{m}^{2}$ & 0 & 2.8/NR & $\begin{array}{l}\text { Neutropenia } \\
5.6 \%\end{array}$ \\
\hline Lin et $\mathrm{al}^{6}$ & Lipo-Dox $^{\circledR}$ & $\begin{array}{l}\text { CDDP-resistant } \\
\text { and paclitaxel- } \\
\text { resistant }\end{array}$ & 18 & $40 \mathrm{mg} / \mathrm{m}^{2}$ & $\begin{array}{l}27.8 \% \text {, three } \\
C R \text {, two } P R\end{array}$ & $3.5 / 12$ & 0 \\
\hline Chou et $\mathrm{al}^{4}$ & Lipo-Dox & $\begin{array}{l}\text { Resistant/ } \\
\text { refractory }\end{array}$ & 29 & $45 \mathrm{mg} / \mathrm{m}^{2}$ & $\begin{array}{l}23 \% \text {, one CR, } \\
\text { five } P R\end{array}$ & $5.4 / 13.8$ & $\begin{array}{l}\text { Neutropenia } \\
12 \%\end{array}$ \\
\hline
\end{tabular}

Abbreviations: $C R$, complete response; PR, partial response; ORR, overall response rate; PFS, progression-free survival; OS, overall survival; NR, not reached; CDDP, diamminedichloroplatinum(II).
Correspondence: Jacqueline M Liu I6F-2, No. 3 Park St, Taipei II503,

Taiwan

Email jmliu@tty.com.tw submit your manuscript | www.dovepress.com

Dovepress

http://dx.doi.org//0.2147/OTT.S79089 


\section{References}

1. Berger JL, Smith AL, Zorn KK, et al. Outcomes analysis of an alternative formulation of PEGylated liposomal doxorubicin in recurrent epithelial ovarian carcinoma during the drug shortage era. Onco Targets Ther. 2014; 7:1409-1413.

2. US Food and Drug Administration. FDA approval of generic version of cancer drug Doxil is expected to help resolve shortage. Available from: http://www.fda.gov/newsevents/newsroom/pressannouncements/ ucm337872.htm. Accessed February 13, 2015.

3. Hong RL, Tseng YL. Phase I and pharmacokinetic study of a stable, polyethylene-glycolated liposomal doxorubicin in patients with solid tumors. Cancer. 2001;91(9):1826-1833.
4. Chou HH, Wang KL, Chen CA, et al. Pegylated liposomal doxorubicin (Lipo-Dox) for platinum-resistant or refractory epithelial ovarian carcinoma: a Taiwanese Gynecologic Oncology Group study with long term follow up. Gynecol Oncol. 2006;101(3):423-428.

5. Fukada T, Wumi T, Teramae M, et al. PEGylated liposomal doxorubicin for platinum-resistant or refractory Mullerian carcinoma: a single institution experience. Oncol Lett. 2013;5(1):35-38.

6. Lin H, Tseng CW, Chang HY, et al. Evaluation of PEGylated liposomal doxorubicin in the treatment of both platinum and paclitaxelrefractory epithelial ovarian cancer. Taiwanese J Obstet Gynecol. 2004;43:140-143.

Dove Medical Press encourages responsible, free and frank academic debate. The content of the OncoTargets and Therapy 'letters to the editor' section does not necessarily represent the views of Dove Medical Press, its officers, agents, employees, related entities or the OncoTargets and Therapy editors. While all reasonable steps have been taken to confirm the content of each letter, Dove Medical Press accepts no liability in respect of the content of any letter, nor is it responsible for the content and accuracy of any letter to the editor.

\section{Publish your work in this journal}

OncoTargets and Therapy is an international, peer-reviewed, open access journal focusing on the pathological basis of all cancers, potential targets for therapy and treatment protocols employed to improve the management of cancer patients. The journal also focuses on the impact of management programs and new therapeutic agents and protocols on

\section{Dovepress}

patient perspectives such as quality of life, adherence and satisfaction. The manuscript management system is completely online and includes a very quick and fair peer-review system, which is all easy to use. Visit http://www.dovepress.com/testimonials.php to read real quotes from published authors.

Submit your manuscript here: http://www.dovepress.com/oncotargets-and-therapy-journal 